\title{
Kan nye blodfortynnende legemidler være mer risikable enn tidligere antatt?
}

\author{
Antallet pasienter som brukte nye blodfortynnende legemidler økte voldsomt i 2013. Som forventet økte også \\ antallet bivirkningsmeldinger. Kan vi ut fra bivirkningsmeldingene trekke noen slutninger om risikoen ved \\ bruk av de nye blodfortynnende legemidlene?
}

Nylig ble bivirkningsrapporten for 2013 lagt frem på Legemiddelverkets nettsider (1). Der fremgår det at Legemiddelverket i 2013 fikk 21 meldinger om dødsfall i forbindelse med warfarinbruk og 19 dødsfall i forbindelse med de nye blodfortynnende midlene dabigatran, rivaroksaban og apiksaban. I 2013 var det om lag 28000 mennesker som fikk de nye blodfortynnende legemidlene og 87000 som fikk warfarin. Antallet meldte dødsfall med nye blodfortynnende midler er betydelig høyere enn for warfarin sett i forhold til antall brukere. Hvilken vekt skal vi legge på disse tallene?

Først og fremst er det viktig å være klar over de mange feilkildene ved bivirkningsmeldinger - eller det vi på fagspråket kaller spontanrapportering. Vanligvis er det en betydelig underrapportering (2). Legemiddelverkets erfaring er at det det meldes flere bivirkninger for nye legemidler enn for eldre. Meldingsskjevhet kan være én årsak til at de nye blodfortynnende midlene tilsynelatende kommer dårlig ut i 2013. Ut fra meldingene kan vi ikke konkludere med at nye antikoagulasjonsmidler gir flere bivirkninger enn warfarin eller er mer risikable enn de kliniske studiene har vist (3-5). Kun større epidemiologiske studier kan fortelle hvordan disse legemidlene fungerer i vanlig praksis.

På den annen side kan nærmere analyse av bivirkningsmeldingene si noe om mulige årsaker eller disponerende faktorer som gjør at bivirkningene oppstår. Dette er nyttig når vi skal utforme praktiske råd til pasienter og leger. Vi ønsker å oppnå best mulig forhold mellom nytten pasienten har av behandlingen og risikoen for bivirkninger. Blodfortynningsbehandling gjør stor nytte, men kan medføre alvorlige bivirkninger og dødsfall. Antallet uheldige hendelser kan reduseres gjennom grundig vurdering av pasientene, riktig valg av legemiddel, oppfølging og bivirkningsforebyggende tiltak.

\section{Dødsårsaker i meldingene}

Dødsfallene som ble meldt i 2013 fordeler seg på ulike hoveddiagnoser. For warfarin var 19 av 21 tilfeller hjerneblødning, for dabigatran var fire av ni tilfeller magetarm-blødninger og for rivaroksaban var fem av ni tilfeller hjerneblødning. Det kan nevnes at $\mathrm{i}$ kliniske studier har dabigatran gitt høyere forekomst av mage-tarm-blødninger enn warfarin (3). Bør dette tas hensyn til ved valg av behandling? Bør pasienter med økt risiko for slike blødninger unngå dabigatran? På dette og mange andre praktiske spørsmål omkring de nye blodfortynnende midlene kan vi i dag ikke gi noe sikkert svar.

Nye studier viser at plasmakonsentrasjonen av dabigatran kan variere betydelig fra pasient til pasient (6). Alder og nyrefunksjon er de faktorene som slår sterkest ut. Gjennomsnittsalderen til de pasientene som ble meldt med dødelige bivirkninger var rundt 80 år. I denne alderen har mange svekket nyrefunksjon, nedsatt kroppsvekt eller bruker mange medisiner - faktorer som bidrar til økt risiko for bivirkninger uansett blodfortynnende legemiddel. Vi kan ikke la være å gi blodfortynnende behandling, men alle leger bør tenke over om det finnes risikoforebyggende tiltak.

\section{Skynde seg langsomt}

Enkelte studier tyder på at bytte fra warfarin til de nye blodfortynnende legemidlene kan medføre økt risiko for bivirkninger (7). I løpet av 2013 økte antallet pasienter som får forskrevet de nye midlene betydelig fordi alle tre medikamenter fikk refusjon som blodproppforebyggende behandling ved atrieflimmer. Foreløpige tall tyder på at mange av pasientene er nye brukere og ikke tidligere warfarinbrukere. Helsedirektoratet og Legemiddelverket anbefaler å være særlig oppmerksom ved bytte fra warfarin til nye blodfortynnende legemidler. Det er viktig at legen gjør en grundig vurdering av hvilket legemiddel som passer best for den enkelte.

De nye blodfortynnende legemidlene vil sammen med warfarin være med oss i mange år. All ny kunnskap som kan bidra til trygg behandling er velkommen. Bivirkningsmeldinger fra leger er et viktig bidrag. Ellers vil epidemiologiske studier være sentrale for å gi oss data fra vanlig praksis. I Norge har vi gode forutsetninger for denne typen studier.

\section{Pernille Harg}

Hilde Samdal

Ane Simensen

Steinar Madsen

steinar.madsen@legemiddelverket.no
Pernille Harg (f. 1975) er cand.pharm. og seniorrådgiver ved Seksjon for legemiddelovervåking, Statens legemiddelverk.

Forfatter har fylt ut ICMJE-skjemaet og oppgir ingen interessekonflikter.

Hilde Samdal (f. 1975) er master i farmasi og seniorrådgiver ved Seksjon for legemiddelovervåking, Statens legemiddelverk.

Forfatter har fylt ut ICMJE-skjemaet og oppgir ingen interessekonflikter.

Ane S. Simensen (f. 1984) er master i molekylærmedisin og forsker ved Seksjon for legemiddelovervåking, Statens legemiddelverk. Forfatter har fylt ut ICMJE-skjemaet og oppgir ingen interessekonflikter.

Steinar Madsen (f. 1956) er medisinsk fagdirektør ved Statens legemiddelverk og deltids avtalespesialist $\mathrm{i}$ indremedisin og hjertesykdommer. Forfatter har fylt ut ICMJE-skjemaet og oppgir ingen interessekonflikter.

\section{Litteratur}

1. Statens legemiddelverk. Bivirkningsrapport for 2013. www.legemiddelverket.no/Bivirkninger/ aarsrapport_bivirkninger/Sider/default.aspx (7.4.2014).

2. Harg $\mathrm{P}$, Lislevand $\mathrm{H}$, Buajordet I et al. Bivirkningsrapportering og legemiddelovervåking. Tidsskr Nor Laegeforen 2003; 123: 331 -2.

3. Connolly SJ, Ezekowitz MD, Yusuf S et al. Dabigatran versus warfarin in patients with atrial fibrillation. N Engl J Med 2009: 361: 1139-51.

4. Patel MR, Mahaffey KW, Garg J et al. Rivaroxaban versus warfarin in nonvalvular atrial fibrillation. N Engl J Med 2011; 365: 883-91.

5. Granger CB, Alexander JH, McMurray JJ et al. Apixaban versus warfarin in patients with atrial fibrillation. N Engl J Med 2011; 365: 981-92.

6. Reilly PA, Lehr T, Haertter S et al. The effect of dabigatran plasma concentrations and patient characteristics on the frequency of ischemic stroke and major bleeding in atrial fibrillation patients: the RE-LY Trial (Randomized Evaluation of Long-Term Anticoagulation Therapy]. J Am Col Cardiol 2014; 63: 321-8

7. Sørensen R, Gislason G, Torp-Pedersen C et al. Dabigatran use in Danish atrial fibrillation patients in 2011: a nationwide study. BMJ Open 2013; 3: e002758.

8. Helsedirektoratet. Informasjon om warfarin og de nye perorale antikoagulasjonsmidlene dabigatran, rivaroksaban og apixaban. www. helsedirektoratet. no/publikasjoner/informasjon-om-de-nyeperorale-antikoagulasjonsmidlene-dabigatranrivaroksaban-og-apiksaban/Sider/ Informasjon-om-warfarin-og-de-nye-peroraleantikoagulasjonsmidlene-dabigatranrivaroksaban-og-apixaban.aspx (7.4.2013). 